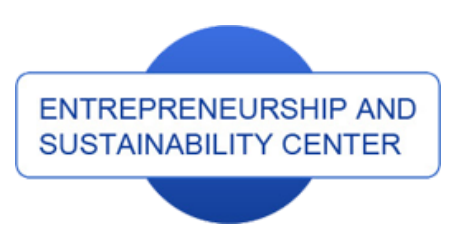

Publisher

http://jssidoi.org/esc/home
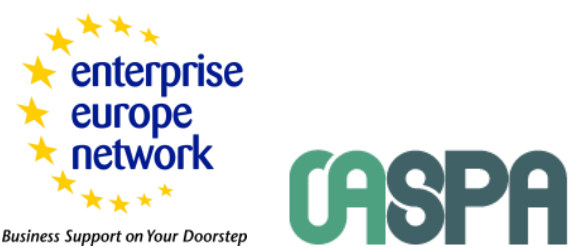

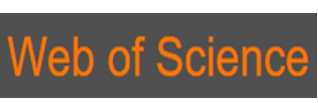

Clarivate
Analytics

\title{
RELATIONSHIP BETWEEN ADMISSION GRADES AND ACADEMIC ACHIEVEMENT
}

\author{
Sulphey, M M'1, Nasser Saad AlKahtani², Abdul Malik Syed ${ }^{3}$ \\ ${ }^{1,2,3}$ College of Business Administration, Prince Sattam Bin Abdulaziz University, Saudi Arabia

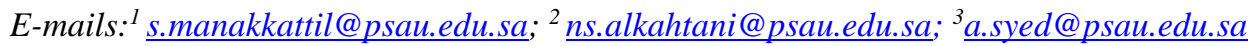

Received 16 November 2017; accepted 20 February 2018; published 30 March 2018

\begin{abstract}
The predictive validity of standardized eligibility test for college admissions is a matter of debate and controversy. Standardized admission test came into vogue in the later part of the previous century. It gained traction due to various reasons. The main reason for this is the heterogeneity of high school GPA and the inherent drawbacks of teacher made tests. Often teacher-made tests fail to follow the basic rules of test construction, and are hence considered to be of poor quality. Standardized admission tests came to be widely accepted due to its presumed scientific predictive validity. Though number of studies has examined the predictive validity of standardized admission tests with respect to various health courses, there is a gap in literature with respect to business students. This study examined the relationship between the admission grades (high school GPA and GAT) of Saudi college students and their academic achievement. The result of the study points towards a strong relationship between the two variables.
\end{abstract}

Keywords: Admission grades, Standardized admission test, Academic achievement

Reference to this paper should be made as follows: Sulphey, M M, AlKahtani, N.S., Abdul Malik Syed, A.M. 2018. Relationship between admission grades and academic achievement, Entrepreneurship and Sustainability Issues 5(3): 648-658. http://doi.org/10.9770/jesi.2018.5.3(17)

JEL Classifications: A2, A29

Additional disciplines: educology; management education

\section{Introduction}

Most graduate programmes stipulate that students meet certain basic academic requirements, to be considered for admission. It is an accepted notion the world over that, due to the marked variance in the quality and system of grading in the high schools, it would be grossly unfair if admission decisions are based solely on high school 
The International Journal

ENTREPRENEURSHIP AND SUSTAINABILITY ISSUES

ISSN 2345-0282 (online) http://jssidoi.org/jesi/

2018 Volume 5 Number 3 (March)

http://doi.org/10.9770/jesi.2018.5.3(17)

grades. As such, it is now a common practice in many countries to have standardized tests for admission to universities (Curtis, Lind, Plesh \& Finzen, 2007; Kuncel et. al., 2005; Shulruf et al., 2010). This could take the form of either aptitude or achievement tests, or both. While aptitude tests focus on assessing the verbal and mathematical abilities and are usually "general" in nature (Koljatic, Silva, and Cofré, 2012); achievement tests are meant to measure accomplishments of the candidates, and are mostly based on certain guidelines and concepts that the students are likely to learn in future (Atkinson, 2001).

Till the recent past, the GPA of the high school examinations were the sole basis on which college admission decisions were taken. This made the chances of admissions to universities and colleges varying from school to school. Admissions used to mostly depend on the quality of education at the school, its location, type, and so on. These differences of individual schools used to yield inconsistent criterion for admissions to universities and colleges. Further, the high school examinations contained several subjects like English, Mathematics, science subjects like physics, chemistry, etc. It is this heterogeneity that prompted educational administrators to design a standardized admission test. According to Beatty, Greenwood \& Linn (1999) there are three benefits standardized admission tests - standardization, efficiency and opportunity. Standardization; because the difference in high school curricula, course content and differing standards in grading standards can be eliminated due to such tests. Efficiency is possible because standardized admission tests can be conducted a relatively low cost to students and are economical and efficient for the institutions as they have the possibility of comparing vast numbers of applicants within a short period of time. Opportunity is possible since students can showcase their talents, even though their academic grades may not be strong or did not have the advantage of attending prestigious schools.

Further, the notion that students with high scores in standardized aptitude and achievement tests are most likely to succeed academically; due to its predictive validity, universities and colleges accord considerable importance to it (Evans, 2012; O'Connor \& Paunonen, 2007). As such better grades in standardized eligibility tests are considered a basic requirement for admission to university programs. This is based on the thought pattern that, learning being an accumulative process, student admitted with higher entry qualification is expected to be well prepared for the course content than those with lower qualifications. A number of studies have been conducted in various parts of the globe to find out the relationship between excellence in eligibility tests and academic performances (AlQataee, 2014; Feldman, 2005; Gropper, 2007; Hughes, 1983; McIntosh and Munk, 2007; Rigney, 2003; Sulphey, 2010; Winter and Dodou, 2011).

As in other parts of the world, students of KSA are provided admission to business programmes based cognitive assessment and non-cognitive assessment. While cognitive assessment is made based on their grades in the qualifying school examinations, the non-cognitive assessment is made based on the standardized eligibility test.

The eligibility test conducted in KSA is the General Aptitude Test (GAT) - also known as "Qiyas", and the standard achievement admission test (SAAT) for science and health colleges. The test is conducted by National Centre for Assessment in Higher Education (NCAHE), which is under the Ministry of Education. The purpose of the standardized testing among other things is "to engage in fair assessment at all levels of education and guide the use of data to promote effective education" (NCAHE, 2010). The format of the test is of multiple choice questions (MCQ) in nature, and each student has a maximum of three attempts while studying in the final year of high school. The best score of all the three attempts is considered for admissions. Normally a student achieving a minimum of 50 per cent score in the test and the eligibility examination is only considered for admission to the graduate programmes conducted by Universities.

The proposed study intends to examine the extent to which the entry qualifications and eligibility tests can be used to predict students' overall academic performance in KSA. Determining the predictive validity of GAT is important as it is the sole basis for screening prospective students entering the University system. It is also the 


\section{The International Journal}

ENTREPRENEURSHIP AND SUSTAINABILITY ISSUES

ISSN 2345-0282 (online) http://jssidoi.org/jesi/

2018 Volume 5 Number 3 (March)

http://doi.org/10.9770/jesi.2018.5.3(17)

basis of identifying applicants for the academic scholarships offered by the Government, regardless of their place of residence, social standing or ethnicity.

\section{Research Problem and objectives}

The world over many studies has been conducted to assess the relationship between the eligibility test scores and academic performance (Evans, 2012; Feldman, 2005; Gropper, 2007; McIntosh and Munk, 2007; Rigney, 2003; Sulphey, 2010; Winter and Dodou, 2011). The results have provided valuable and interesting insights into this area. A few studies in this area have also been undertaken in KSA (Abu Zaid, Khunaizi, and Garni, 2014; AlAlwan, 2009; Alnahdi, 2015; Hitchcock, Onwuegbuzie, and Khoshaim, 2014). However, most of these studies examined either medical or related disciplines like dental, nursing, etc. A fair review of literature could not identify studies that examine the relationship between standardized eligibility tests and academic performance among business students in Saudi Arabia.

The study focuses on and explores the relationship between the scores earned in the eligibly tests and the academic scores earned by the students. The insights of the study would be of great interests to academicians and academic administrators as it would provide valuable suggestions to improve the intake quality of the students. It will also be of wider importance in the interests of the Saudi academic circles, the organisations who employ them and the society in general. Based on this, the research objectives identified for the present study are:

1. To investigate into the predictive validity of standardized eligibility tests on:

a. Students' performance in preparatory course

b. Students' future academic achievements

2. To find out the relationship between the family background and academic achievement of students.

\section{Literature review}

The world over there exist wide heterogeneity in the admission process of various graduate and masters academic programs, though most of them are based on the scorings of standardized eligibility tests. Some such prominent standardized tests include SAT (Scholastic Aptitude Test), CAT (Common Aptitude Test), the GMAT (Graduate Management Admission Test), etc. Most of these eligibility examinations test the students about their verbal and mathematical ability.

In KSA the eligibility test conducted for graduate admission is GAT. All Saudi students desirous of gaining admission to any university are required to take GAT. The test measures the analytical and deductive abilities of students. The test is so designed that it examines the student's general capacity for learning, without focusing on any specific subject or topic. The abilities/skills that are tested in GAT include reading comprehension, recognizing of logical relations, problem solving using mathematics, inference and measuring capacity (www.qiyas.sa). It also considers the potential of the student to learn, in addition to the proficiency in a particular area of study. Universities in Saudi Arabia generally consider both GA and the high school GPA. Some institutions also consider the scores earned in and achievement assessment test known as National Achievement Test (NAT). Different universities and colleges uses varying formula for weighing the three scores for generating a single score for admission decisions.

The school GPA is often found to be independent of GAT performance. There are ample instances wherein students who perform considerably well at high school examinations fail to do so in GAT. This is often a matter of grave concern among parents and education administrators. This variance in student performance has also raised many unanswered questions. Some academicians attribute this variance to the school curricula, which lays emphasis more on memorization than application of knowledge as well as critical thinking. Many educators are 
now of the opinion that GAT has provided a level playing field with respect to college admissions (Hitchcock, et al, 2014). It is also opined that the family connections, which previously might have determined access to college is now waned due to the emphasis on standardized test.

Standardized tests have gained traction all over the globe, due to its presumed scientific predictive validity, and the inherent drawbacks of teacher made tests. It is often found that the teacher made tests seldom follow the basic rules of test construction, and are hence of poor quality. Other drawbacks of such tests include lack of representation for examining cognitive abilities, non-checking of difficulty and discrimination power, etc. (Carter, 1984; Jandaghi, 2010; Reynolds and Menard, 1980; Stiggins and Bridgeford, 1985; Stiggins, Griswold and Wikelund, 1989). Teacher made testes are also found to heavily rely (at times around 90\%) on "recall items" (Carter, 1984). This could be attributed to the lack of experience of teachers in developing questions that help measure cognitive levels of the students (AlQataee, 2014). MacCuish (1986), after surveying over 100 teachers about classroom test design, found that most of them failed to design their tests properly and even evaluate the test responses scientifically. All these point to the definite need and requirement of having scientifically prepared and tested standardised testing tools for college admissions.

\section{Relationship between high school GPA and future academic performance}

There are quite a few evidences to show that high school GPA is a significant predictor or performance at the graduation level. While Platt, Turocy and McGlumphy (2001) found positive association among US students; Wharrad, Chapple and Price (2003) found the same association in UK. A similar positive relation was also found in KSA among nursing students by Ayyaf and Magzoub (2014). The same results were found by many researchers (Ali, 2008; Downey, Collins \& Browning, 2002 Shulruf et al., 2010; Smithers, Catano and Cunningham, 2004). All these studies were however conducted among medical students.

\section{Relationship between standardized tests and academic performance}

There is substantial literature regarding the relationship between standardized entrance examinations and college performance (Alnahdi, 2015; Feldman, 2005; Gropper, 2007; Hitchcock, Onwuegbuzie, and Khoshaim, 2014; Hughes, 1983; McIntosh and Munk, 2007; Rigney, 2003; Sulphey, 2010; Winter and Dodou, 2011). The results these studies are, however, inconclusive and are often conflicting. For instance, Ringney (2003) found that students with high scores in the standardized eligibility scores performed better. An earlier study by Astin (1993) observed that the high school GPA and standardized test scores are predictors of success in university GPA. Another noteworthy study was by Ferguson, James and Madeley (2002). They conducted a detailed review of literature regarding the factors that are associated with academic success. The review, which was limited to medical students, examined the productive validity of selection tests. The study focused on eight criteria under two factors - cognitive and non-cognitive. The cognitive factor analyzed by them was previous academic achievement. The non-cognitive factors were demographics, personality, learning styles, interviews, references, and personal statements. The study observed that there is fairly good correlation between previous academic performance and undergraduate medical training.

A comprehensive study by Bean and Metzner (1985) found that the decision of students' to drop out of college is based on four variables. This included background factors, academic performance, intend to leave, and external factors. The first variable included the demographics of the students, earlier performance, and their goals and expectations. Academic performance variable included certain aspects like their grades in individual courses, study habits and the major opted by the student at college. "Intend to leave" is a psychological variable, which included commitment of the student to his/her goal, the perceived utility they place of the degree and satisfaction 
with the institution. The external factor includes aspects like financial background of the student, family commitments, etc.

As mentioned earlier, inconsistent results have been found in the relationship between standardized admission tests and future academic performance. A number of studies have found the opposite (Feldman, 2005; McIntosh and Munk, 2007; Wright and Palmer, 1997). For instance Feldman (2005) and Gropper (2007) observed only a weak link between eligibility scores and the overall academic performance. Wright and Palmer (1997) found no relationship between the standardized eligibility test scores and academic success of business graduates. McIntosh and Munk (2007) have also opined in the same lines. In a study on Indian population Sulphey (2010) found that there is no relationship between the eligibility test scores and the overall academic performance among business students. Smithers, et al., (2004), on a population of Canadian dental students, found that the effectiveness of the standardized admission test to predict future performance diminishes beyond the second year of study.

\section{Relationship between academic performance and a combination of high school GPA and standardized test performance}

Many studies have empirically verified the relationship between future academic performance and the combination of both standardized test scores and high school GPA. Results show that the combination even outperformed either of the one in a consistent manner (Wiley, 2014). A few studies which demonstrated this include Burton and Ramist (2001), Julian (2005), Kobrin, Patterson, Shaw, Mattern and Barbuti (2008), Kuncel, Crede and Thomas (2007), Noble (2003), Stilwell, Dalessadro and Reese (2007). For instance, the study by Kobrin et al., (2008) found an incremental increase in the predictive validity by .08 when the two were taken together. An extensive review was conducted by Burton and Ramist (2001) to evaluate the ability of standardized test and high school GPA to predict future performance. They concluded that a combination of both the scores were capable of making significant and accurate contributions to predict first year GPA, cumulative college GPA, as well as graduation. It was also found that the prediction accuracy was more with the combination of the two either of them. The two are even capable of predicting even certain academic behaviours at college like distinction and other departmental honors.

Significant contribution was made by Kuncel and Hezlett (2007) to this area of research in the form of a metaanalysis. They examined the ability to predict academic performance in both graduate as well as professional college programs. Four key results were found by them. Standardized admission tests were found to effectively predict performance in graduate colleges. A combination of the two was found to predict academic outcomes; over and above the graduate grades at college. The standardized tests predicted were capable of predicting successful performance than college GPA. Another significant finding was that a combination of college GPA and standardized test scores was capable of providing the best accurate prediction. However, these findings were observed for graduate students.

Mattern and Patterson (2011) examined the ability of high school GPA and standardized eligibility tests to predict the retention in the second and third years of college study. The study found that students who, in addition to having standardized test scores, had high school GPA reported correspondingly higher retention rates in the second and third years of their study. However, this study was limited to examining the retention rates and not the academic performance per se. 


\section{Saudi studies}

A few studies have been conducted in KSA to find out the relationship between standardized test scores and academic performance. Al-Alwan (2009), in a study among health sciences students sample, found that the cognitive components of Saudi GAT exhibited significant correlation with the progress and future academic performance. AlQataee (2014), on a sample of over 5000 students, conducted a study to found out the predictive validity of GAT. Results of the study suggested the predictive validity of the test. However, the sample did not include business students and results of only the first two years of study were considered. The predictive validity of GAT and high school GPA in KSA was examined by Alshumrani (2007). It was found that they both predictors approximately 11 per cent of first-semester college GPA. While GPA explained 10 per cent of GPA variation, GAT could explain only one per cent.

Thus the efficacies of standardized admission tests are still a matter of controversy and debate. Evans (2012) of Stanford University made a prophetic comment when he stated that despite heated discussion over the utility and efficacy of standardized tests for admission to universities, such tests "will continue to play an important role in college admission for the foreseeable future". This statement seems to be correct, without exception, the world over.

A fair review of literature has found that studies about the relationship between standardized eligibility tests and future academic performance and achievement; especially in business studies are scarce. There is a definite need for such a study. The present study attempts to fill this gap in literature. The result of the study will be of great significance to the academia and educational administrators alike, and will be of interests to professionals in the industry.

\section{Research methodology}

Data was collected from a sample of 1368 undergraduate business students pertaining to nine academic years of a University in Saudi Arabia. All the students were either graduated or have completed/exhausted the maximum number of attempts/years provided for graduation. Their basic high school qualifications of the sample included specialisations in science, arts and commerce. Details pertaining to high school GPA, standardized eligibility scores and final GPA of the graduated students were used for analysis. They belonged to varied socio-economic status and both genders. The demographics of the sample are presented in Table 1.

Table 1. Demographics of the sample

\begin{tabular}{|l|l|c|c|}
\hline \multicolumn{1}{|c|}{ Particulars } & Number & Per cent \\
\hline \multirow{4}{*}{$\begin{array}{l}\text { High school } \\
\text { specialization }\end{array}$} & Science & 1102 & 80.56 \\
\cline { 2 - 4 } & Arts & 248 & 18.12 \\
\cline { 2 - 4 } & Commerce & 18 & 1.32 \\
\cline { 2 - 4 } & Total & 1368 & 100 \\
\hline \multirow{3}{*}{$\begin{array}{l}\text { Status at the end of } \\
\text { the study period }\end{array}$} & Graduated & 181 & 13.23 \\
\cline { 2 - 4 } & Dismissed/Found incapable & 235 & 17.18 \\
\cline { 2 - 4 } & Withdrawn/Discontinued & 952 & 69.59 \\
\cline { 2 - 4 } & Total & 1368 & 100 \\
\hline
\end{tabular}

It can be seen from Table 1 that the maximum number of students with science $(1102-80.56$ per cent $)$ as major in their high schools has joined the university business program. Students with commerce at high schools were only 18 ( 1.32 per cent) in number. This shift in majors while moving to college education presents a rather perplexing scenario. Further, Table 1 also presents another disturbing trend. The numbers of students who 


\section{The International Journal}

ENTREPRENEURSHIP AND SUSTAINABILITY ISSUES

ISSN 2345-0282 (online) http://jssidoi.org/jesi/

2018 Volume 5 Number 3 (March)

http://doi.org/10.9770/jesi.2018.5.3(17)

graduate are just above 10 percent, with majority either withdrawing or discontinuing their studies in between. While some are dismissed or found to be not fit to continue studies, a large majority of them drop out on their own volition. High dropout rate in Saudi Arabia is definitely a malady that faces the Saudi higher education scenario, which need to be addressed in a war footing (Sulphey, 2017; Sulphey and Alkahtani, 2018). This should not happen given the fact that a large chunk of students join public universities and are often granted scholarships for carrying on their studies. High dropout rates are definitely a serious the world over. It is estimated that in the US though around two-thirds of students who pass out of the high school join colleges, only around 30 per cent go on to graduate after the four-year period. This phenomenon of falling graduation rates is reported to have been occurring since the 1970s (Geisinger, 2014; Hauptman and Kim, 2009; Kamenetz, 2010). Definitely this is an area that needs to be explored to find out the causative factors, so that remedial actions can be taken.

\section{Analysis}

The descriptive statistics has presented some interesting findings. The mean University GPA of students who studied science at high school was found to be higher $(\mathrm{M}=1.18$ and $\mathrm{SD}=1.346)$ than those who studied arts $(\mathrm{M}$ $=.90$ and $\mathrm{SD}=1.164)$ or commerce $(\mathrm{M}=.60$ and $\mathrm{SD}=1.039)$. The choice of optional courses by students at high schools need be studied; as to whether they are considering optional based on their own interests, volition and motivation, or are they being impressed upon by family and friends circles.

An attempt was also made to find out if there existed any differences in final outcome of university studies and the standardized admission tests. Towards this ANOVA was done, and there was found to be significant difference $(\mathrm{F}=17.551)$ at 0.01 level between those graduated students and those who could not do this due to some reason (dismissed or discontinued) based on the standardized admission test. The Post hoc (Scheffe) also revealed significant difference in the standardized admission test of those who have graduated and the other groups who could not. This shows the discriminating capability of the standardized admission test. The same pattern was also found in the case of high school GPA. The ANOVA results $(F=61.760)$ showed significant difference between the graduated students and those who failed to do so. The pattern with respect to Post hoc was also the same as in the earlier case. This presents that those students who had better high school GPA maintained the same trend with respect to college GPA too.

With a view to find out the relationship between the variables (High school GPA, standardized admission tests and University GPA), and in tune with a number of earlier studies, correlation analyses were done. The analyses have presented some significant results. It was found that significant correlation existed at 0.01 level $(r=.236)$ between high school GPA and standardized admission test). These also existed significant correlation $(\mathrm{r}=.194)$ between the standardized admission test and the overall university GPA. This denotes that there is significant positive relationship between the standardized admission tests score and the overall university GPA. The high school GPA was also found to be significantly correlated at 0.01 level $(r=.237)$ with the overall university GPA. These findings are in consistency with the findings of an earlier study by Platt et al., (2001) and another by AlAlwan (2009) with a Saudi sample. Both these studies, however, were conducted among students undergoing health education. The finding is also in consistency with the findings Ringney (2003), Ferguson, James and Madeley (2002) and Wharrad et al., (2003). Both these findings found that scores of standardized eligibility tests is a definite predictor of success in university GPA. However, all these studies were conducted among health sciences students. Since no other studies have been found to be conducted among business students, this finding is of definite significance and importance.

To understand the predictor power of the individual variables regression analysis was done and the results are presented in the following sections. Table 2 presents the simple and hierarchical multiple regressions. 
Table 2. Regression Analysis of Admission Criteria as Predictors of Student Grade Point Average (GPA) at College level

\begin{tabular}{|l|c|c|c|}
\hline \multicolumn{2}{|c|}{ B } & 95\% CI & P-value \\
\hline \multicolumn{7}{|c|}{ Univariate analysis } \\
\hline High school GPA & .045 & .035 to .056 & .000 \\
\hline GAT & .035 & .026 to .044 & .000 \\
\hline \multicolumn{1}{|c|}{ Multivariate analysis } \\
\hline High school GPA & .039 & .029 to .049 & .000 \\
\hline GAT & .026 & .017 to .036 & .000 \\
\hline
\end{tabular}

This model denotes that HS GPA predicts that University GPA increases by .045 . Similarly the Generalized admission test predicts University GPA by .035. Multiple regression was done to find out the possible interaction between both the predictor variables and the University GPA. It can be seen that the final model also predicts that the High school GPA and Generalized Admission Test scores are predictors of the University GPA. The ANOVA values in both instances were also significant at 0.01 level, thereby denoting that the regression model is adequate. The above findings are in consistency with the findings of AlQataee (2014), and Ayyaf and Magzoub (2014). However, as stated earlier the present work seems to be the only work which has been done to find out the predictive validity of the HS GPA and standardized admission scores among business students.

\section{Conclusion}

Admissions based on standardized eligibility tests have always been a matter of controversy. This has been so in both developed and developing parts of the world. For instance, in the US it is a practice to conduct standardized tests in almost all levels of university education. This system has been criticized for long by academicians and researchers, teacher unions and other civil rights organizations in the US (de Lange, 2007; Hitchcock, et al., 2014), and the public attitude are split about this matter (Bushaw and Lopez, 2012). In the US quite a few civil and grass root organizations see such tests as unfair and discriminatory (Blair, 1999), and have even filed civil suits. Further, students are often pressurised to prepare for the Standardized Admissions tests, whereby they spend hours towards this. Due to this, there are many academic experts who argue that such over emphasis on tests are a compromising and distorting the overall educational system. However, in the absence of a viable alternative, such standardized eligibility tests will continue to be used widely the world over.

Though a number of studies about the efficacy of standardized admission tests have been conducted in the developed world, and quite a few in certain developing countries, only few studies are found conducted in KSA. The study has brought out the complex relationship between performances is eligibility tests and future academic achievement of business students. The present study has also bridged the gap in literature in this regard. It has succeeded in establishing the predictive power of HS GPA and standardized admission scores among business undergraduate students. A combination of HS GPA standardized test scores seems to be the best option for considering students for admission to colleges. Timely modifications of both the examinations based on the changing trends in the education sector will go a long way in making it ideal for selecting students for college admission - at least till another more scientific way of screening students is established. The results of the study have provided inputs for devising strategies to make the eligibility tests and the process of admissions more scientific and professional. The study has also provided educational administrators with valuable insights in this regard. It is expected that further studies, with a higher sample with a wider geographic spread will furthering the results of the study.

Further, a potential area of research is the re-enrolment of dropped out students. The idea stems from the fact that the dropout rate of Saudi students seems to be on the higher side. The aspect of re-enrolment of dropped out students was a matter of study by a number of social scientists and researchers. Studies by Aragon \& Johnson (2008); Boston, et al, (2011); Morris \& Finnegan (2009) dedicated variables like student characteristics, grades 
The International Journal

ISSN 2345-0282 (online) http://jssidoi.org/jesi/

2018 Volume 5 Number 3 (March)

http://doi.org/10.9770/jesi.2018.5.3(17)

earned in the courses, number of credits that could be transferred, competency with respect to e-learning environments and course load as predicting the possible re-enrolment of the dropped out students on a later stage. It would be ideal if universities devised appropriate regulations for the transfer of earlier credits, create e-learning environments, blended learning, etc. There seems to be vast potential for e-learning and blended learning platforms in Saudi Arabia in particular and the Middle East and North African region in general. It is hoped that educational administrators do take the required and appropriate steps in this direction. It is also expected and hoped that the present study will act as a trigger for further studies in this line and bring in worthwhile suggests that would help in better the educational scenario in the region.

\section{References}

Abu Zaid, I. T., Khunaizi, M. A. M and Garni, H. H, (2014). Saudi Aramco Screening Process for High School Graduates: Legacy, of Validation Studies, Proceedings of the First International Conference on Assessment \& Evaluation, Riyadh: The National Center for Assessment in Higher Education.

Al-Alwan, I. A. (2009). Association between Scores in High School, Aptitude and Achievement Exams and Early Performance in Health Science College, Saudi Journal of Kidney Disease and Transplantation, 20(3), $448-453$. http://www.sjkdt.org/text.asp?2009/20/3/448/50777

Ali, P. (2008). Admission criteria and subsequent academic performance of general nursing diploma students. JPMA, 58(3), 32-128. https://www.ncbi.nlm.nih.gov/pubmed/18517117

Alnahdi, G. H. (2015). Aptitude Tests and Successful College Students: The Predictive Validity of the General Aptitude Test (GAT) in Saudi Arabia, International Education Studies, 8(4), 1-6, http://dx.doi.org/10.5539/ies.v8n4p1

AlQataee, A. A. (2014). The effect of the Distributions of College Course Grades on the NCA Admission Test Predictive Validity, Proceedings of the First International Conference on Assessment \& Evaluation, Riyadh: The National Center for Assessment in Higher Education.

Aragon, S. R. and Johnson, E. S. (2008). Factors influencing completion and non-completion in online community college courses. American Journal of Online Education, 22(3), 146-158. http://dx.doi.org/10.1080/08923640802239962

Atkinson, R. (2001). Achievement versus aptitude tests in college admissions. Issues in Science and Technology, 18(2), 15-23. http://issues.org/18-2/atkinson-2/

Ayyaf, A. H. M. and Magzoub, M. E. (2014). Admission Criteria as Predictors of Student Academic Performance in the College of Nursing, Proceedings of the First International Conference on Assessment \& Evaluation, Riyadh: The National Center for Assessment in Higher Education.

Bean, J. P., \& Metzner, B. S. (1985). A conceptual model of nontraditional undergraduate student attrition. Review of educational Research, 55(4), 485-540. https://doi.org/10.3102/00346543055004485

Beatty, A., Greenwood, M. R. C., and Linn, R. L. (Eds.). (1999). Myths and tradeoffs: The role of tests in undergraduate admissions. Washington, D.C.: National Research Council. https://doi.org/10.17226/9632

Boston, W., Diaz, S. R., Gibson, A. M., Ice, P., Richardson J., and Swan, K. (2011). An exploration of the relationship between indicators of the community of inquiry framework and retention in online programs. Journal of Asynchronous Learning Networks, 13(3), 6783. http://citeseerx.ist.psu.edu/viewdoc/download?doi=10.1.1.474.6112\&rep=rep1\&type=pdf

Burton, N. W. and Ramist, L. (2001). Predicting success in college: SAT studies of classes graduating since 1980 (College Board Research Report 2001-02). New York, NY: The College Board http://mc-3241-1259741632.us-east1.elb.amazonaws.com/sites/default/files/publications/2012/7/researchreport-2001-2-predicting-college-success-sat-studies.pdf

Bushaw, W. J. and Lopez, S. J. (2102). The 44th annual Phi Delta Kappa/Gallup Poll of the public's attitudes toward the public schools: Public education in the United States: A nation divided, 94(1), kappanmagazine.org. Retrieved from http://www.pdkintl.org/poll/docs/2012-Galluppoll-full-report.pdf.

Curtis, D. [et. al.]. (2007). Correlation of admission criteria with academic performance in dental students. Journal of Dental Education, 71(10), 21-1314. https://www.ncbi.nlm.nih.gov/pubmed/17923709

De Lange, J. (2007). Large-scale assessment and mathematics education. In F. K. Lester, Jr. (Ed.). Second handbook of research on mathematics teaching and learning: A project of the National Council of Teachers of Mathematics, 2, 1111-1142. Charlotte, NC: Information Age.

Evans, B. J. (2012). College Admission Testing in America. Retrieved from https://cepa.stanford.edu/sites/default/files/Draft\%20of\%20College\%20Testing\%20in\%20America.pdf

Feldman, D. C. (2005). The food's no good and they don't give us enough: Reflections on Mintzberg's critique of MBA education. Academy of Management Learning \& Education, 4(2), 217-220.

Ferguson, E., James, D. and Madeley, L. (2002). Factors associated with success in medical school: Systematic review of the literature. British Medical Journal, 324, 952-957. https://www.ncbi.nlm.nih.gov/pubmed/11964342 


\section{The International Journal}

ENTREPRENEURSHIP AND SUSTAINABILITY ISSUES

ISSN 2345-0282 (online) http://jssidoi.org/jesi/

2018 Volume 5 Number 3 (March)

http://doi.org/10.9770/jesi.2018.5.3(17)

Geiser, S and Santelices, M. V. (2007). Validity of high-school grades in predicting student success beyond the freshman year: HighSchool Record vs. Standardized Tests as Indicators of Four-year College Outcomes https://files.eric.ed.gov/fulltext/ED502858.pdf

Geisinger, K. F. (2014). The Future Content of Admissions Testing in America, Proceedings of the First International Conference on Assessment \& Evaluation, Riyadh: The National Center for Assessment in Higher Education.

Gropper, D. M. (2007). Does the GMAT Matter for Executive MBA Students? Some Empirical Evidence, Academy of Management Learning \& Education, 6 (2), 206-216. http://dx.doi.org/10.5465/AMLE.2007.25223459

Hitchcock, J. H., Onwuegbuzie, A. J. and Khoshaim, H. B. (2014). Examining the Consequential and Social Validity of College Entrance Exams in Saudi Arabia: Mixed Method Survey Design Considerations, Proceedings of the First International Conference on Assessment \& Evaluation, Riyadh: The National Center for Assessment in Higher Education.

http://www.qiyas.sa/Sites/English/Tests/EducationalTests/Pages/General-Aptitude-Test-(GAT).aspx

Hughes, O. L. (1983). A Comparison of Error Based and Time Based Learning Measures as Predictors of General Intelligence, Intelligence, 7, 9-26. http://dx.doi.org/10.1016/0160-2896(83)90003-X

Jandaghi, G. (2010). Assessment of validity, reliability and difficulty indices for teacher-built physics exam questions in first year high school. Educational Research and Reviews, 651-654. http://www.academicjournals.org/article/article1379652980_Jandaghi.pdf

Julian, E. (2005). Validity of the Medical College Admission Test for predicting medical school performance. Academic Medicine, 80, 910

- 917. https://www.ncbi.nlm.nih.gov/pubmed/16186610

Kobrin, J. L., Patterson, B. F., Shaw, E. J., Mattern, K. D., and Barbuti, S. M. (2008). Validity of the SAT for predicting first-year college grade point average (College Board Research Report No. 2008-5). New York, NY: The College Board.

Koljatic, M., Silva, M., and Cofré, R. (2012). Achievement versus aptitude in college admissions: A cautionary note based on evidence from Chile. International Journal of Educational Development, 33(1), 106-115. http://dx.doi.org/10.1016/j.ijedudev.2012.03.001

Kuncel, N. [et. al.]. (2005). A meta-analysis of the validity of the pharmacy college admission test (PCAT) and grade predictors of pharmacy student performance. American Journal of Pharmaceutical Education, 69(3), 47-339. https://www.aacp.org/sites/default/files/ajpemetaanalysisjune2005.pdf

Kuncel, N. R., and Hezlett, S. A. (2007). Standardized tests predict graduate students' success. Science, 315, 1080-1081. http://dx.doi.org/10.1126/science.1136618

Kuncel, N. R., Crede, M. \& Thomas, L.L. (2007). A meta-analysis of the predictive validity of the graduate management admission test (GMAT) and undergraduate grade point average for graduate student academic performance. Academy of management learning and education, 6, 51-68.

MacCuish, D. A. (1986). The course development model in higher education: improving tests and instruction. ED273169.

Mattern, K. D. and Patterson, B. F. (2011). The relationship between SAT scores and retention to the second year: 2007 SAT Validity Sample. (College Board Research Report 2011-4). New York: College Board.

McIntosh, J. and Munk, M.D. (2007). Scholastic ability vs family background in educational success: evidence from Danish sample survey data, Journal of Population Economics, 20, 101-120. http://vbn.aau.dk/da/publications/scholastic-ability-vs-family-background-ineducational-success-evidence-from-danish-sample-survey-data(2c5d8080-7d04-11de-9240-000ea68e967b)/export.html

Morris, L. V. \& Finnegan, C. L. (2009). Best practices in predicting and encouraging student persistence and achievement online. Journal of College Student Retention, 10(1), 5-34. https://doi.org/10.2190/CS.10.1.e

National Center for Assessment in Higher Education (2010). Retrieved from http://www.qiyas.org/Qiyas/Exams/QaboolSGExams.aspx

Noble, J. (2003). The effect of using ACT composite score and high school average on college admission decisions for racial/ethnic groups (ACT Research Report RR2003-1). Iowa City, IA: ACT Inc.

O'Connor, M. C., and Paunonen, S. V. (2007). Big Five personality predictors of post-secondary academic performance. Personality and Individual Differences, 43(5), 971-990. http://dx.doi.org/10.1016/j.paid.2007.03.017

Platt, L., Turocy, P., and Mc Glumphy, B. (2001). Preadmission criteria as predictors of academic success in entry-level athletic training and other allied health educational programs. Journal of Athletic Training, 36(2), 4-141. https://www.ncbi.nlm.nih.gov/pmc/articles/PMC155524/

Rigney T.J. (2003). A Study on the Relationship between Entry Qualifications and Achievement of Third Level Business Studies Students, The Irish Journal of Management, 117-138.

Shulruf, B., [et. al.]. (2010). Rethinking the Admission Criteria to Nursing School. Nursing Education Today. http://dx.doi.org/10.1016/j.nedt.2010.11.024

Smithers, S., Catano, V., and Cunningham, D. (2004). What predicts performance in Canadian dental Schools? Journal of Dental Education, 68(6), 598-613.

Stiggins, R. J., and Bridgeford, N. F. (1985). The ecology of classroom assessment. Journal of Educational Measurement, 22, $271-286$.

Stiggins, R. J., Griswold, M. M., and Wikelund, K. R. (1989). Measuring thinking skills through classroom assessment. Journal of Educational Measurement, 26 (3), 233-246. http://dx.doi.org/10.1111/j.1745-3984.1989.tb00330.x

Stilwell, L. A., Dalessadro, S. P, and Reese, L. M. (2007). Predictive validity of the LSAT: A national summary of the 2005-2006 correlation studies (Law School Admission Council LSAT Technical Report). Newtown, PA: Law School Admission Council. https://www.lsac.org/docs/default-source/research-(lsac-resources)/tr-16-01.pdf 
The International Journal

ENTREPRENEURSHIP AND SUSTAINABILITY ISSUES

ISSN 2345-0282 (online) http://jssidoi.org/jesi/

2018 Volume 5 Number 3 (March)

http://doi.org/10.9770/jesi.2018.5.3(17)

Sulphey, M. M. (2010). Does High Scores in Eligibility Tests Guarantee Academic Performance? A Study among B-School Participants, The Indian Journal of Technical Education, 33(1), 84-90.

Sulphey, M. M. (2017). Game based learning as an aid for extenuating Higher Education Sector issues - The case of Saudi Arabia. International Journal of Simulation, Systems, Science and Technology, 18 (1), 6.1-6.10. https://doi.org/10.5013/IJSSST.a.18.01.06

Sulphey, M. M. and Alkahtani, N. S. (2018). Academic Excellence of Business Graduates through Nudging: Prospects in Saudi Arabia, International Journal of Innovation and Learning (in print)

Wharrad, H., Chapple, M., and Price, N. (2003). Predictors of academic success in bachelor of nursing course. Nursing Education Today, 23, 54-246.

Wiley, A. (2014). Student success in college: How criteria should drive predictor development. Proceedings of the First International Conference on Assessment \& Evaluation, Riyadh: The National Center for Assessment in Higher Education.

Winter. J. C. F. De, and Dodou. D. (2011). Predicting Academic Performance in Engineering Using High School Exam Scores.

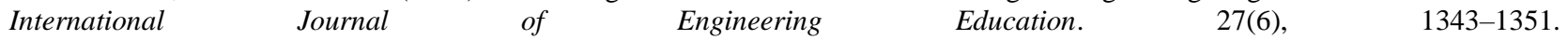
http://www.ece.uvic.ca/ rexlei86/SPP/otherswork/19_ijee2519ns.pdf

\section{Aknowledgements}

This project was supported by the Deanshipof Scientific Research at Prince Sattam Bin Abdulaziz University, Al-Kharj, Saudi Arabia under the research project \#2017/02/8035

Short biographical note about the contributors at the end of the article (name, surname, academic title and scientific degree, duties, research interests):

Dr Sulphey, M M is Professor, College of Business Administration, Prince Sattam Bin Abdul Aziz University, Al-Kharj, Saudi Arabia. He has published research articles in many international journals about various topics. He has also published a few books with reputed international publishers. His research interests include OB/HRM, teaching learning process, sustainability, etc.

ORCID ID: https://orcid.org/0000-0001-6042-2123

Dr Nasser Saad AlKahtani is Dean, College of Business Administration, Prince Sattam Bin Abdul Aziz University, Al-Kharj, Saudi Arabia. Dr. Nasser is involved in many activities of the Univeristy and has also published a number of research articles in many international journals. His research interests include various areas in OB and HRM.

Dr. Abdul Malik Syed is Faculty, Department of Finance, College of Business Administration, Prince Sattam Bin Abdul Aziz University, Al-Kharj, Saudi Arabia. His research interests include Finance, Banking, etc.

ORCID ID: https://orcid.org/0000-0001-5593-7405

Register for an ORCID ID:

https://orcid.org/register

Copyright (C) 2018 by author(s) and VsI Entrepreneurship and Sustainability Center

This work is licensed under the Creative Commons Attribution International License (CC BY).

http://creativecommons.org/licenses/by/4.0/

cC) (i) Open Access 